\section{PCR amplification of large VNTR alleles of D17S5 (YNZ22) locus}

\section{J.Gécz}

Institute of Molecular Physiology and Genetics, Department of Human Genetics, Vlárska 5, 83334 Bratislava, Czechoslovakia

The VNTR locus detected by probe YNZ22 (D17S5) 17p13.3 chromosome represents one of the most informative polymorphic regions identified so far in the human genome (1). By now 11 alleles have been detected, ranging in length from $170 \mathrm{bp}$ (allele B1) to 870 bp (allele B11) with overall heterozygosity reaching $86 \%(1,2)$. When amplifying this segment by PCR, the preferential amplification of smaller alleles has been observed (2), which may create problems in interpreting the results and/or lead to a loss of allele detection.

In order to improve amplification of large alleles, we designed a new PCR protocol based on lower temperature and longer time of the extension step. After the long denaturation step $\left(96^{\circ} \mathrm{C}\right.$ for 8 minutes) and enzyme addition step $\left(70^{\circ} \mathrm{C}\right.$ for 2 minutes), 27 rounds of following cycle were performed: $94^{\circ} \mathrm{C}$ for $1 ; 56^{\circ} \mathrm{C}$ for 1 and $65^{\circ} \mathrm{C}$ for 7 minutes, respectively. Using this protocol we found in a sample of 72 unrelated Caucasians two additional large alleles containing 12 (B12 940 bp; 6 alleles found) and 14 (B14; $1080 \mathrm{bp} ; 1$ allele found) repeat units, respectively (Fig. 1). Thus the total number of D17S30 VNTR alleles increased to at least 14, though one of them (allele B13; $1010 \mathrm{bp}$ long) remained not yet detected. The heterozygosity observed increased to $88 \%$.

References: 1) Nakamura,Y. et al. (1987) Science 235, 1616-1622. 2) Horn,G. et al. (1989) Nucl. Acids Res. 17, 2140.
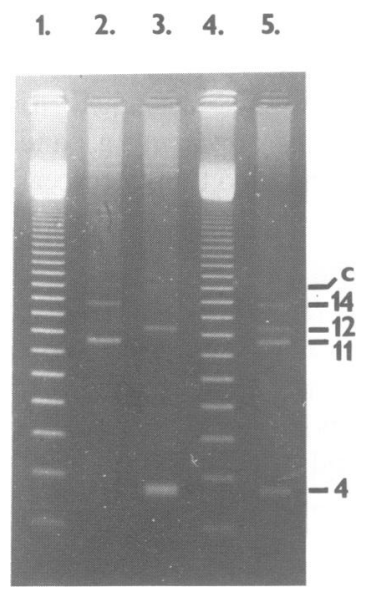

Figure 1. Ethidium bromide stained $1.5 \%$ agarose showing the two new alleles containing 14 (B14) (lane 2) and 12 (B12) (lane 3) 70 bp repeat units, respectively. New alleles were successfully amplified also when both DNA samples (as in lanes 2 and 3) had been mixed prior to PCR amplification (lane 5). For PCR amplification the primers already published were used (2) in a total reaction volume of $50 \mu \mathrm{l}$ containing $1 \mu \mathrm{M}$ of each primer, $0.8 \mathrm{mM}$ total dNTPs, $50 \mathrm{mM} \mathrm{KCl}$, $10 \mathrm{mM}$ Tris- $\mathrm{HCl} \mathrm{pH}=9.0,2.5 \mathrm{mM} \mathrm{MgCl} 2,0.1 \%$ Triton X-100, $170 \mu \mathrm{g} / \mathrm{ml}$ BSA and 2U of Taq polymerase (ESP Fermentas, USSR). 100 bp ladder (Pharmacia, Sweden) was used as a molecular weight marker. c-constant band

\section{Mspl RFLP of the human TCR gamma chain variable gene V9 (TCRGV9)}

\author{
E.Martínez-Naves, M.Peña, V.Alvarez, F.Setién and \\ C.López-Larrea \\ Servicio de Inmunologia, Hospital Central de Asturias, \\ 33006, Oviedo, Spain
}

Source and Description of Clone: pV9PH is a $700 \mathrm{bp} \mathrm{Pst//HindIII}$ fragment isolated from $\lambda \mathrm{SHV} 7$ (1), containing TCR Gamma Chain Variable Region V9 gene (2), cloned in PUC vector.

Polymorphism: MspI identifies a two-allele-RFLP with fragments of a $900 \mathrm{bp}$ (allele A1) and $700 \mathrm{bp}$ (allele A2). No constant bands are detected (See Figure 1).

Frequency: Estimated from 30 Spanish unrelated individuals

$\mathrm{A} 1=0.47$

$\mathrm{A} 2=0.53$

$\mathrm{PIC}=0.37$

Not Polymorphic For: EcoRI, HindIII, TaqI, SacI and PstI.

Chromosomal Location: Has been localised to 7p15 (3).

Mendelian Inheritance: Codominant segregation was observed in three 2-generation families with 14 members.

Probe Availability: $\mathrm{Dr}$ M.P. Lefranc, Laboratoire d'Immunogénétique Moléculaire, URA CNRS 199, Université des Sciences et Techniques du Languedoc. Place E. Bataillon, F-34060. Montpellier Cedex 1, France.

Other Comments: The genomic DNA source was peripheral blood leucocytes. Standard hybridization and washing conditions.

Acknowledgements: We thank Dr M.P. Lefranc for providing the TCR gamma variable chain probe. This work was supported by a grant FISS $89 / 0370$.

References: 1) Forster,A. (1987) EMBO J. 6, 1945-1950. 2) Lefranc,M.P. (1986) Nature 319, 420-422. 3) Murre et al. (1985) Nature 316, 549-552.

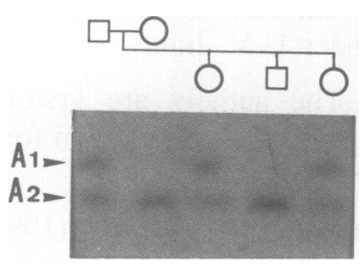

